УДК 34.07

\title{
А.В. Гапонов
}

\section{КОМПЕТЕНЦІЯ ТА ПОВНОВАЖЕННЯ СУДІВ У СИСТЕМІ СУДОВОЇ ВЛАДИ УКРАЇНИ (НА ПРИКЛАДІ СУДІВ АПЕЛЯЦІЙНОЇ ІНСТАНЦЇ̈)}

У статті проаналізовано поняття судової влади, ї̈ основні функиії, надано авторську класифікацію функиій судової влади на основні та допоміжні. Досліджено поняття повноважень суду апеляційної інстанції, надано авторські пропозииії до змін чинного законодавства.

Ключові слова: судова влада, функиії судової влади, апеляційний суд, повноваження, компетенція.

\section{DOI 10.34079/2226-3047-2019-9-18-23-30}

Постановка проблеми: Еволюція державних інституцій в Україні задля забезпечення сталого економічного розвитку передбачає створення стабільно функціонуючої системи правосуддя, одним 3 керуючих принципів якої $є$ принцип правової визначеності, який, зокрема, за переконанням Європейського суду з прав людини, є одним з фундаментальних аспектів верховенства права [1]. У зв'язку з цим постає питання про визначення розмежування в компетенції та повноваженнях судів, зокрема апеляційної інстанції, як суб'єктів судової влади.

Актуальність теми дослідження полягає в тому, що наразі в чинному законодавстві нормативно не закріплено поняття компетенції судів апеляційної інстанції, а у сучасній юридичній науці триває дискусія про зміст функцій, повноважень та компетенції судів апеляційної інстанції. Нормативне вирішення цих проблем $є$ актуальною в умовах триваючої судової реформи в Україні.

Огляд останніх досліджень і публікацій. Слід згадати роботи В.Е. Теліпка, С.Д. Гусарєва, Є.Є. Матякіна, Е.Б. Аблаєвої, Р.М. Чариєва, В.І. Анішиної, В.М. Скрипнюк, М.М. Суховія, С.С.Алексєєва, В.М. Горшеньова, Д.А. Керімова, В.С. Бігуна, В.Я. Горбачевського, М.І. Чичерської, О.А. Калашник, М.Л. Шелухіна, які досліджували поняття судової влади, іiі вплив на якість правової системи, співвідношення понять компетенції та повноважень суду $[2 ; 3 ; 4 ; 5 ; 6 ; 7 ; 8 ; 9 ; 10 ; 11 ; 12 ; 13 ; 14 ; 15 ; 16 ; 17]$. Водночас, поза увагою дослідників залишились окремі питання щодо аналізу функцій судової влади та судів апеляційної інстанції зокрема.

Формулювання завдання дослідження. Метою дослідження $є$ на підставі результатів аналізу різноманітних підходів навести авторське визначення терміну «судова влада», надати авторську класифікацію функцій судової влади, а також пропозицій 3 удосконалення чинного законодавства у сфері повноважень судів апеляційної інстанції.

Виклад основного матеріалу. Чинна редакція Конституції України правове визначення судової влади зводить лише до констатації іiі як складової тріумвірату державної влади, поряд із законодавчою та виконавчою [18].

Крім цього, частина 2 статті 6 Конституції України носить бланкетний характер та відсилає до чинного національного законодавства.

Стаття 1 Закону України «Про судоустрій і статус суддів» не наводить безпосередній зміст судової влади, незважаючи на назву статті. При цьому, у статті наведено перелік суб'єктів іï здійснення (незалежні та безсторонні суди, утворені 
законом), а також перелік суб'єктів, що ії реалізують (судді та, у визначених законом випадках, присяжні шляхом здійснення правосуддя у рамках відповідних судових процедур) [19].

Через брак легального визначення цього поняття необхідно звернутись до доктринальних тлумачень.

В. Є. Теліпко зазначає про існування декількох підходів до тлумачення поняття «судова влада». На його, думку, існують організаційний, функціональний та організаційно-функціональний підходи. Проте, сутності поняття він не надає, а дотримується організаційно-функціонального підходу.

Н.В. Заяць зазначає, що термін «судова влада» вживається в різних значеннях. Можна стверджувати, що судова влада - це суд, система відповідних установ, або всі суди. Конституція України містить розділ «Судова влада», де закріплено норми, що визначають не лише компетенцію різних судів, але й основи побудови судової системи, правове положення суддів, принципи судової діяльності.

Судова влада - це вид влади, яку здійснюють відповідні органи. Влада - це не тільки ті чи інші установи, посадові особи, але й ті функції, які їм належать, здійснення цих функцій та їх реалізація. Аналізуючи поняття судової влади було б неправильно вести мову про неї як про державний орган, влада - це те, що цей орган може зробити в силу своїх можливостей, це повноваження, функція, але не іiі виконавець. I тому, говорячи про будь-яку владу необхідно вести мову не про орган чи систему органів, що iï здійснюють, а про право, засновану на праві можливість цих органів виконувати відповідні дії та саме виконання цих дій [3, С. 84]

Інші дослідники під поняттям «судова влада» розуміють самостійне публічноправове утворення, що уявляє собою систему спеціальних державних та муніципальних органів, що мають визначені законом владні повноваження, спрямовані на з'ясування істини, поновлення справедливості, вирішення спорів та покарання винуватих, рішення яких обов'язкові до виконання особами, яких вони стосуються.

Деякі вчені характеризують поняття судової влади через аналіз особливостей, притаманній лише ній у контексті принципу поділу державної влади на три гілки, зокрема, незалежність судової влада, іiі самостійність, іiі обов'язковий характер, iii примусовий характер тощо [5, с. 196].

3 урахуванням викладеного, вбачається прийнятним надати визначення поняття судової влади як виду державної влади, що здійснюється судами та іншими державними органами відповідно до компетенції, основною метою діяльності яких $є$ здійснення правосуддя в установленому законом порядку.

Зарубіжні та українські вчені розподіляють функції судової влади країн СНД на основні (базові) та допоміжні (факультативні). При цьому В. Анішина, В. Скрипнюк, Р.Чариєв і у своїх працях відносять до основних функцій судової влади правосуддя, судовий контроль, конституційний контроль. Р. Чариєв до основних функцій відносить i тлумачення Конституції. Вказані автори вважають допоміжними функції судового нагляду, виховну, попередження правопорушень, законодавчу ініціативу, узагальнення судової практики, аналіз судової статистики тощо [6, с.9; 8, с. 74]

Так, М. Суховій пропонує класифікувати функції судової влади на зовнішні, що впливають і діють на широке коло суб'єктів, внутрішні та змішані.

До зовнішніх функцій він відносить функції правосуддя та судового контролю. До внутрішніх функцій судової влади, за його думкою, належать функції судового управління та суддівського самоврядування. До комбінованих (змішаних) належать правотворча, виховна та профілактична функції. 
За підходами С. Алексєєва, В. Горшеньова та І. Шахова, Д. Керімова функції судової влади можна класифікувати як такі, що пов'язані зі здійсненням правосуддя, постановлення судового рішення; такі, що спрямовані на забезпечення судового контролю за органами дізнання, слідства під час досудового провадження; із забезпечення гарантій прав i свобод людини i громадянина у кримінальному судочинстві.

Проаналізувавши вищевикладені класифікації функцій судової влади, вважаємо прийнятним класифікувати їх як основні та додаткові (допоміжні). При цьому, до першої групи доцільно віднести функцію правосуддя, судового контролю під час досудового розслідування та забезпечення контролю за дотриманням конституційних прав i свобод людини i громадянина. До допоміжних слід віднести функції суддівського самоврядування, судового управління, узагальнення судової практики тощо.

Погоджуючись із тезами про першочерговість у визначенні в понятті судової влади саме притаманних їй функцій, необхідно визначити їх особливості.

Так, найважливішою, на наш погляд, функцією судової влади є здійснення правосуддя.

Вважаємо слушною думку С. П. Погребняка, що «Саме здійснення правосуддя $€$ однією 3 необхідних процедур, завдяки якій стає можливим поєднання права зі справедливістю. Невипадково термін “iustitia" має одночасно два значення правосуддя і справедливість, а судова система багатьох держав називається юстицією» $[13$, c. 72$]$.

Ідея справедливості як мети правосуддя закріплена і в процесуальних кодексах України. Зокрема, ч. 1 ст.2 Цивільного процесуального кодексу України завданням цивільного судочинства визначає справедливий, неупереджений та своєчасний розгляд і вирішення цивільних справ. Схожим чином справедливий розгляд і вирішення судової справи закріплено у відповідних статтях Кодексу адміністративного судочинства України, господарському та кримінальному процесуальних кодексах України [20, 21, 22, 23].

Важливою функцією для забезпечення конституційних прав особи при провадженні досудового розслідування $є$ судовий контроль на стадії досудового розслідування. 3 цього приводу В. Я. Горбачевський зазначає, що: «Слідчий суддя - це фігура в кримінальному судочинстві держави, яка виконує роль арбітра сторін обвинувачення і захисту на стадії досудового слідства, а також здійснює судовий контроль за додержанням прав і свобод осіб у кримінальному провадженні. Саме слідчий суддя приймає рішення про застосування запобіжного заходу та продовження його терміну, видає санкції на слідчі дії, які обмежують права людини, ...».

Особливим видом судового контролю доречно вважати контроль за законністю та обгрунтованістю рішень i дій державних органів, посадових осіб i державних службовців у випадку їх оскарження в суді, зокрема, судовий контроль за законністю адміністративної діяльності органів Державної фіскальної служби.

У сучасній науковій думці не заперечується факт, що єдиним суб'єктом здійснення правосуддя через процедуру судочинства $\epsilon$ лише суд в особі (під головуванням) суддів шляхом конституційного, цивільного, адміністративного та кримінального судочинства. Судочинство передбачає законодавче регулювання всього порядку діяльності суду шляхом встановлення процесуальної процедури, що гарантує права та свободи особи, законність і справедливість рішень суду.

Таким чином, національну систему судової влади доцільно розглянути через судову систему України. 
Остання утворює нормативно визначену чітку та ієрархічну структуру - систему судоустрою України. Розглянемо ії складові.

Згідно з ч. 3 ст. 17 Закону України «Про судоустрій і статус суддів», систему судоустрою України складають місцеві суди, апеляційні суди та Верховний суд. Для розгляду окремих категорій справ відповідно до цього Закону в системі судоустрою діють вищі спеціалізовані суди.

Стаття 21 вищевказаного закону надає нормативне визначення місцевих загальних судів, якими є окружні суди, що утворюються в одному або декількох районах чи районах у містах, або у місті, або у районі (районах) і місті (містах). Окремими видами місцевих судів є окружні господарські та окружні адміністративні суди.

Правовому статусу судів першої інстанції приділено достатньої уваги з боку вітчизняних та іноземних вчених-правознавців [24; $11 ; 12]$.

Про легальне закріплення ролі судів апеляційної інстанції у системі судоустрою України свідчить Конституція України, пунктом 8 частини першої статті 129 якої серед основних засад судочинства зазначено забезпечення права на апеляційний перегляд справи.

Відповідно до ст. 26 Закону України «Про судоустрій і статус суддів», апеляційні суди діють як суди апеляційної інстанції, а у випадках, визначених процесуальним законом, - як суди першої інстанції, 3 розгляду цивільних, кримінальних, господарських, адміністративних справ, а також справ про адміністративні правопорушення.

3 легального визначення апеляційних судів необхідно зробити висновок, що вони переглядають (розглядають) судові справи за всіма вищевказаними процесуальними кодексами України, тобто до їх юрисдикції належить перегляд (у визначених законом випадках - розгляд) усіх судових справ, підсудних місцевим судам.

Функції та компетенцію апеляційних судів у системі судоустрою, на наш погляд, не коректно грунтовно розглядати без дослідження їх повноважень.

Так, у чинній редакції Закону України «Про судоустрій і статус суддів» до повноважень апеляційного суду віднесено здійснення правосуддя у порядку, встановленому процесуальним законом; аналіз судової статистики, вивчення та узагальнення судової практики, інформування про результати узагальнення судової практики відповідних місцевих судів, Верховний Суд; надання місцевим судам методичної допомоги в застосуванні законодавства; здійснення інших повноважень, визначених законом. При цьому, легального визначення поняття «повноваження»у законі не наведено.

Слід зазначити, що наразі у сучасній науці не усталено єдиного підходу до поняття «повноваження». В деяких тлумачних словниках синонімом поняття «повноваження» виступає поняття «компетенція» [25, с.469]. При цьому термін «компетенція» необхідно розуміти як «... сукупність встановлених в офіційній юридичній чи не юридичній - формі прав і обов'язків, тобто повноважень будь-якого органу або посадової особи, які визначають можливості цього органу або посадової особи приймати обов'язкові до виконання рішення...» [25, с.196].

Водночас, тлумачний словник під терміном «повноваження» у широкому сенсі вбачає право, надане кому-небудь для здійснення чого-небудь [26].

Таким чином, визначення напрямів діяльності апеляційного суду терміном «повноваження» свідчить про наявність у нього лише прав для їх здійснення.

Проаналізувавши зміст наведених понять, необхідно зробити висновок, що термін «компетенція» та «повноваження» співвідносяться як ціле та його складова. Адже 
компетенція містить у собі не лише правомочність органу або посадової особи приймати обов'язкові до виконання рішення, а й відповідне коло обов'язків, на що також служно вказує В.М. Коротун [27].

Обов'язки апеляційного суду щодо прийняття рішень згідно його повноважень виходять зі змісту приписів процесуальних кодексів України. Наприклад, стаття 398 Кримінального процесуального кодексу України передбачає імперативну норму щодо передачу апеляційної скарги, що надійшла до суду апеляційної інстанції, суддідоповідачу не пізніше наступного дня. А повноваження апеляційного суду щодо можливості винесення варіантів судового зазначені у частині 1 статті 407 цього ж Кодексу.

Аналогічні за своїм змістом норми щодо обов'язків та повноважень апеляційного суду щодо перегляду судових рішень закріплені у ст. 357 та ст. 374 Цивільного процесуального кодексу України.

3 урахування викладеного, приходимо до висновку, що термін «повноваження», що використаний законодавцем у статті 27 Закону України «Про судоустрій і статус суддів» не відображає у повній мірі зміст діяльності апеляційного суду.

Таким чином, для подолання нормативно закріпленої невідповідності змісту поняття «повноваження» основним напрямам діяльності судів апеляційної інстанції пропонується змінити назву статті 27 закону України «Про судоустрій і статус суддів» 3 «Повноваження апеляційного суду» на «Компетенція апеляційного суду».

Висновки. Підсумовуючи вищевикладене, необхідно зробити висновок про різноманітність існуючих в юридичній науці підходів до визначення та характеристики поняття судової влади. Множинність підходів характерна як для української юридичної думки, так і для закордонних представників юридичної галузі.

3 урахуванням викладеного, вбачається прийнятним навести визначення поняття судової влади як виду державної влади, що здійснюється судами та іншими державними органами відповідно до компетенції, основною метою діяльності яких $\epsilon$ здійснення правосуддя в установленому законом порядку.

Проаналізувавши класифікації функцій судової влади, вважаємо прийнятним класифікувати їх як основні та додаткові (допоміжні). При цьому, до першої групи доцільно віднести функцію правосуддя, судового контролю під час досудового розслідування та забезпечення контролю за дотриманням конституційних прав і свобод людини i громадянина. До допоміжних слід віднести функції суддівського самоврядування, судового управління, узагальнення судової практики тощо.

Для подолання нормативно закріпленої невідповідності змісту поняття «повноваження» основним напрямам діяльності судів апеляційної інстанції пропонується змінити назву статті 27 закону України «Про судоустрій і статус суддів» 3 «Повноваження апеляційного суду» на «Компетенція апеляційного суду».

\section{Список використаної літератури}

1. BRUMĂRESCU v. ROMANIA. № 28342/95. § 61. 28 November 1995. URL: http://eurocourt.in.ua/Article.asp?AIdx=307.

2. Закон України «Про судоустрій і статус суддів»: науково-практичний коментар / за ред. проф. Молдована В. В. К.: Центр учбової літератури, 2011. 526 с.; Zakon Ukrainy «Pro sudoustrii i status suddiv»: naukovo-praktychnyi komentar / za red. prof. Moldovana V. V., K.: Tsentr uchbovoi literatury, 2011. $526 \mathrm{s.}$

3. Теорія держави та права: навчальний посібник / Є. В. Білозьоров, В. П. Власенко, О. Б. Горова, А. М. Завальний, Н. В. Заяць та ін. / за заг. ред. С. Д. Гусарєва, О. Д. Тихомирова. К.: НАВС, Освіта України, 2017. 320 с.; Teoriia derzhavy ta prava : 
navchalnyi posibnyk / Ye. V. Bilozorov, V. P. Vlasenko, O. B. Horova, A. M. Zavalnyi, N. V. Zaiats ta in. / za zah. red. S. D. Husarieva, O. D. Tykhomyrova. K.: NAVS, Osvita Ukrainy, 2017. $320 \mathrm{~s}$.

4. Матякин Е. Е. Понятие судебной власти: постановка проблемы / Е. Матякин // Общество и право. 2011. № 3. С. 72-74; Matiakyn E. E. Poniatye sudebnoi vlasty: postanovka problemi / E. Matiakyn // Obshchestvo y pravo. 2011. № 3. S. 72-74.

5. Аблаева Э.Б. Судебная власть в РК: ее место и роль в механизме разделения властей / Э. Аблаева // Пробелы в российском законодательстве. 2017. № 1. С. 194-20; Ablaeva E.V. Sudebnaia vlast v RK: ee mesto y rol v mekhanyzme razdelenyia vlastei / E. Ablaeva // Probeli v rossyiskom zakonodatelstve. 2017. № 1. S. 194-201.

6. Чарыев Р. М. Функции судебной власти / Р. Чарыев // Правосудие в Российской Федерации. 2002. № 3. С. 7-11; Chariev R. M. Funktsyy sudebnoi vlasty / R. Chariev // Pravosudye v Rossyiskoi Federatsyy. 2002. № 3. S. 7-11.

7. Анишина В.И. Основы судебной власти и правосудия в Российской Федерации: курс лекций. Москва: Эксмо, 2008. 270 с.; Anyshyna V.I. Osnovi sudebnoi vlasty i pravosudyia v Rossyiskoi Federatsyy: kurs lektsyi. Moskva: Eksmo, 2008. 270 s.

8. Скрипнюк В. Функції правосуддя в структурі державної влади в Україні / В. Скрипнюк // Юрид. Україна. 2005. № 2 (26). С. 70-76; Skrypniuk V. Funktsii pravosuddia v strukturi derzhavnoi vlady v Ukraini / V. Skrypniuk // Yuryd. Ukraina. 2005. № 2 (26). S. 70-76.

9. Суховій М.М. Правовий статус інституту судової влади у контексті судовоправової реформи в Україні: дис. канд. юрид. наук : 12.00.10 / М.М.Суховій; ПВН3 «Львів. ун-т бізнесу та права». Л., 2012. 240 с.; Sukhoviy M.M. Pravovyi status instytutu sudovoi vlady u konteksti sudovo-pravovoi reformy v Ukraini: dys. kand. yuryd. nauk : 12.00.10 / M.M.Sukhoviy; PVNZ «Lviv. un-t biznesu ta prava». L., 2012. 240 s.

10. Алексеев С.С. Общая теория права. Т. 1 / С.С. Алексеев. М.: Юрид. лит., 1981. - 360 c.; Alekseev S.S. Obshchaia teoryia prava. T. 1 / S.S. Alekseev. M.: Yuryd. lyt., 1981. $360 \mathrm{~s}$.

11. Горшенев В.М. Контроль как правовая форма деятельности / В. М. Горшенев, И. Б. Шахов. М.: Юрид. лит. 1987. 176 с.; Horshenev V.M. Kontrol kak pravovaia forma deiatelnosty / V. M. Horshenev, Y. B. Shakhov. M.: Yuryd. lyt. 1987. 176 s.

12. Керимов Д.А. Общенаучная методология и методология права / Д. Керимов // Теоретико-методологические проблемы права. М.: ИКД «Зерцало-М». 2007. 18 с.; Kerymov D.A. Obshchenauchnaia metodolohyia i metodolohyia prava / D. Kerymov // Teoretyko-metodolohycheskye problemi prava. M.: YKD «Zertsalo-M». 2007. 18 s.

13. Правосуддя: філософське та теоретичне осмислення: колективна монографія / А. М. Бернюков, В. С. Бігун, Ю. П. Лобода, Б. В. Малишев, С. П. Погребняк, С. П. Рабінович, В. С. Смородинський, О. В. Стовба / За ред. В. С. Бігун. К., 2009. 316 с.; Pravosuddia: filosofske ta teoretychne osmyslennia: kolektyvna monohrafiia / A. M. Berniukov, V. S. Bihun, Yu. P. Loboda, B. V. Malyshev, S. P. Pohrebniak, S. P. Rabinovych, V. S. Smorodynskyi, O. V. Stovba / Za red. V. S. Bihun. K., 2009. 316 s.

14. Горбачевський В. Я. Судовий контроль на стадії досудового розслідування / В. Горбачевський // Південно-український правничий часопис. 2014. № 3. С. 243-246. URL: http://nbuv.gov.ua/UJRN/Pupch_2014_3_77; Horbachevskyi V. Ya. Sudovyi kontrol na stadii dosudovoho rozsliduvannia / V. Horbachevskyi // Pivdenno-ukrainskyi pravnychyi chasopys. 2014. № 3. S. 243-246. URL: http://nbuv.gov.ua/UJRN/Pupch_2014_3_77.

15. Чичерська М. I. Правовий статус місцевого суду та його втілення у функціях структурних одиниць із забезпечення роботи суду / М. Чичерська // Науковий вісник Ужгородського національного університету. Серія: Право. 2016. № 40(2). С. 142-146; 
Chycherska M. I. Pravovyi status mistsevoho sudu ta yoho vtilennia u funktsiiakh strukturnykh odynyts iz zabezpechennia roboty sudu / M. Chycherska // Naukovyi visnyk Uzhhorodskoho natsionalnoho universytetu. Seriia: Pravo. 2016. № 40(2). S. 142-146.

16. Калашник О. А. Правовий статус місцевих загальних судів в Україні : дис. ... канд. юрид. наук : 12.00.10 / О.А. Калашник. Одеса, 2016. - 231 с.; Kalashnyk O. А. Pravovyi status mistsevykh zahalnykh sudiv v Ukraini : dyc. ... kand. yuryd. nauk : 12.00.10 / O.A. Kalashnyk. Odesa, 2016. - 231 s.

17. Шелухин Н.Л. О целесообразности введения в юридических вузах специализации по криминологии и профилактике преступлений / Н.Л. Шелухин, А.Н. Шелухин. - DOI: 10.17150/2500-4255.2019.13(5).707-717 // Всероссийский криминологический журнал. - 2019. - Т. 13, № 5. - С. 707-717; Shelukhyn N.L. O tselesoobraznosty vvedenyia $v$ yurydycheskykh vuzakh spetsyalyzatsyy po krymynolohyy y profylaktyke prestupleniy / N.L. Shelukhyn, A.N. Shelukhyn. - DOI: 10.17150/25004255.2019.13(5).707-717 // Vserossyiskyi krymynolohycheskyi zhurnal. - 2019. - T. 13, № 5. - S. 707-717.

18. Конституція України: Закон України від 28.06.1996 // Відомості Верховної Ради України. 1996. № 30. Ст. 141; Konstytutsiia Ukrainy: Zakon Ukrainy vid 28.06.1996 // Vidomosti Verkhovnoi Rady Ukrainy. 1996. № 30. St. 141.

19. Про судоустрій і статус суддів: Закон України від 02.06.2016 № 1402-VIII // Голос України від 16.07.2016. № 132-133; Pro sudoustrii i status suddiv: Zakon Ukrainy vid 02.06.2016 № 1402-VIII // Holos Ukrainy vid 16.07.2016. № 132-133.

20. Цивільний процесуальний кодекс України: Закон України від 18.03.2004 № 1618-IV // Офіційний вісник України. 2004. № 16. Ст. 1088; Tsyvilnyi protsesualnyi kodeks Ukrainy: Zakon Ukrainy vid 18.03.2004 № 1618-IV // Ofitsiinyi visnyk Ukrainy. 2004. № 16. St. 1088.

21. Кримінальний процесуальний кодекс України: Закон України від 13.04.2012 № 4651-VI // Голос України від 19.05.2012. № 90-91; Kryminalnyi protsesualnyi kodeks Ukrainy: Zakon Ukrainy vid 13.04.2012 № 4651-VI // Holos Ukrainy vid 19.05.2012. № 9091.

22. Кодекс адміністративного судочинства України: Закон України від 06.07.2005 № 2747-IV // Урядовий кур'єр. 2005. № 153; Kodeks administratyvnoho sudochynstva Ukrainy: Zakon Ukrainy vid 06.07.2005 № 2747-IV // Uriadovyi kurier. 2005. № 153.

23. Господарський процесуальний кодекс України: Закон України від 06.11.1991 № 1798-IX // Відомості Верховної Ради України. 1992. № 6. Ст. 56; Hospodarskyi protsesualnyi kodeks Ukrainy: Zakon Ukrainy vid 06.11.1991 № 1798-IX // Vidomosti Verkhovnoi Rady Ukrainy. 1992. № 6. St. 56.

24. Медведик Л. Правовий статус судових органів України як суб’єктів юрисдикційних відносин / Л. Медведик // Вісник Національного університету «Львівська політехніка». Юридичні науки. 2017. № 861. С. 560-566; Medvedyk L. Pravovyi status sudovykh orhaniv Ukrainy yak subiektiv yurysdyktsiinykh vidnosyn / L. Medvedyk // Visnyk Natsionalnoho universytetu «Lvivska politekhnika». Yurydychni nauky. 2017. № 861. S. 560-566.

25. Юридична енциклопедія : в 6 т. / редкол. : Ю. С. Шемчушенко (голова редкол.) та ін. К. : Укр. енцикл., 2001. - Т. 3: К-М. - 792 с.; Yurydychna entsyklopediia : v 6 t. / redkol. : Yu. S. Shemchushenko (holova redkol.) ta in. K. : Ukr. entsykl., 2001. - T. 3: K-M. $-792 \mathrm{~s}$.

26. Словник української мови: в 11 томах / АН УРСР. Інститут мовознавства; за ред. І. К. Білодіда. - К.: Наукова думка, 1970-1980.Т. 6, С. 684; Slovnyk ukrainskoi 
movy: v 11 tomakh / AN URSR. Instytut movoznavstva; za red. I. K. Bilodida. - K.: Naukova dumka, 1970-1980.T. 6, S. 684.

27. Коротун В. М. Функції апеляційного суду через призму понятійного апарату / В. Коротун // Адвокат. 2012. № 8. C. 35-37; Korotun V. M. Funktsii apeliatsiinoho sudu cherez pryzmu poniatiinoho aparatu / V. Korotun // Advokat. 2012. № 8. S. 35-37.

\section{A. Gaponov \\ COMPETENCE AND AUTHORITIES OF COURTS IN THE SYSTEM OF JUDICIARY IN UKRAINE (ON THE CASE OF COURT OF APPEALS)}

The article highlights the notion of the judiciary, its main functions and provides an author's classification of the judiciary's functions into basic and auxiliary ones. The concept of the powers of the court of appeals is investigated, the author's proposals for changes to the current legislation are given.

Keywords: judiciary, functions of the judiciary, Court of Appeal, powers, competence. Стаття надійшла до редакції 07.10.2019 р.

УДК 343.983

\section{Н.В. Мітько}

\section{ПОНЯТТЯ ІНФОРМАЦЙНО-ПОШУКОВИХ СИСТЕМ ЕКСПЕРТНОЇ СЛУЖБИ МВС УКРАЇНИ У БОРОТЬБІ ЗІ ЗЛОЧИННІСТЮ}

Однозначність та повнота правового регулювання створення $і$ використання «інформаційно-пошукових систем» Експертної служби МВС Украӥни у боротьбі зі злочинністю залежить від однозначності визначення цього поняття та подальшого його тлумачення. В статті проаналізовано доктринальні підходи до визначення поняття «інформаційно-пошукові системи».

Ключові слова: інформація, інформачійна система, інформачійно-пошукова система (ІПС), автоматизована інформаційно-пошукова система (АІПС), криміналістичні обліки.

DOI 10.34079/2226-3047-2019-9-18-30-40

Вступ. У сучасних умовах практично жодне судово-експертне дослідження не проводиться без інформаційної підтримки, без звернення до новітніх інформаційнопошукових систем. Затребуваність інформаційно-пошукових систем поряд з активним вдосконаленням криміналістичних методів і засобів автоматизації обумовлюють високі темпи розвитку даного напрямку роботи Експертної служби МВС України. Таким чином, особливого теоретичного значення потребує визначення поняття «інформаційно-пошукових систем» Експертної служби МВС України як джерела оперативного одержання інформації про конкретний об'єкт дослідження, а також порядку використання різних сучасних автоматизованих систем і комплексів в цілях ефективного використання їх у боротьбі зі злочинністю.

Проблеми визначення поняття «інформаційно-пошукових систем» Експертної служби МВС України у боротьбі зі злочинністю є одним з найдавніших і недостатньо 